\title{
TYPES AND FORMS OF «POLYCHROME MARBLE WARE» FROM THE OTTOMAN FORTRESS OF AZAK IN SOUTHERN RUSSIA (CERAMOLOGICAL STUDY)
}

\author{
By \\ Walid cAli Khalil \& Irina Rudolfovna Gusach \\ Associate Professor of Islamic Archaeology Dept., Faculty of Archaeology, Fayoum University, Egypt . \\ Senior staff scientist of the Azov History, Archaeology and Palaeontology Museum-Reserve, Azov, \\ Russia.
}

\begin{abstract}
This ceramological research is devoted to a very rare type of marble-like decorated glazed pottery «Polychrome Marble Ware» - that was discovered during archaeological excavations between 1961 and 2015 in the Ottoman fortress of Azak in the North-East Azov region, Southern Russia. This provided the first possibility to identify and study fragments of this tableware, which are now stored in the stock collections of Azov History, Archaeology and Paleontology Museum-Reserve. The authors of this ceramological research set themselves the following tasks: to study the history of the origin of the Ottoman "Polychrome Marble Ware»; to determine the centers of its production and the time of its existence,; as well as to define and classify the types and forms of these vessels, which were encountered during excavations in the Turkish fortress of Azak, by finding analogies in other archaeological sites of the Ottoman time. The research results are reflected in four sections of this article. In our opinion, most of the «Polychrome Marble Ware» was brought to the Turkish fortress Azak from Anatolia, where it was produced in the $17^{\text {th }}-18^{\text {th }}$ centuries. Among this assemblage, there is clearly also pottery from the coast of the Marmara Sea and the South-East Crimea. Crimean potters, apparently, imitated Italian and Malaysian tableware with marble decor that was then fashionable.
\end{abstract}

KEYWORDS: Southern Russia, Ottoman fortress of Azak, «Polychrome Marble Ware», $17^{\text {th }}-18^{\text {th }}$ centuries. 


\section{TYPES AND FORMS OF «POLYCHROME MARBLE WARE» FROM THE OTTOMAN FORTRESS OF AZAK IN SOUTHERN RUSSIA (CERAMOLOGICAL STUDY)}

\section{INTRODUCTION}

The study of ceramic complexes of the remote Ottoman military fortress of Great Porte-Azak (for the Russians, Azov), which was first collected more than half a century ago during archaeological research (beginning 1961) within the territory of this historic Middle Age-Modern site in North-East Azov region (Southern Russia) [FIGURE 1], showed that the imported polychrome tableware included a small percentage of «Polychrome Marble Ware». Due to their small number and poor condition, these artefacts had largely been overlooked by researchers who, in the late $20^{\text {th }}$ - early $21^{\text {th }}$ centuries, were studying the archaeological collections stored in the Azov History, Archaeology and Paleontology Museum-Reserve (Azov city, Rostov region). However, a detailed review of the collections from excavations in the 1960s and 1970s at the former Turkish fortress Azak, showed that the inhabitants of these fortifications used such utensils in their daily lives. ${ }^{1}$ In the Azov collections, we found 22 fragments of earthenware with marble decoration (17open-shaped vessels, 3 closed-shaped vessels, 2 jug lids) [FIGURES 2/2-5; 3/ 8; 4/2, 6-8].

In the 1980s and 1990s, archaeological research in the territory of the former Ottoman fortress of Azak was almost stopped. Excavations of this historical site and its surroundings at this time were rare and insignificant in scale. The ceramic collection of the Azov Museum-Reserve during this period was enriched, as it turned out, by only one fragment of a plate with a marble ornament, which was discovered in 1994 in the vicinity of the fortress [FIGURES 2/1]. ${ }^{2}$

A noticeable influx of new ceramics of the Ottoman period into the Azov MuseumReserve took place in the first two decades of the $21^{\text {th }}$ century, when archaeological research in the territory of Turkish Azak and its districts intensified again. Thanks to the 2004-2015 excavations in Azov, ${ }^{3}$ the number of «Polychrome Marble Ware» increased by another 56 pieces [FIGURES 2/6-9; 3/1-7; 4/1, 3-5].

We firstly discovered the "Polychrome Marble Ware» in 79 fragments from archaeological sites of the Ottoman period in the North-East Azov region. This material has been studied, attributed and dated based on an analysis of the results of archaeological excavations in the Turkish fortress of Azak, as well as a search for analogies at archaeological sites around the Black Sea and the Mediterranean. A particular concern at this stage of the study is an identification of the production centers for the «Polychrome Marble Ware» that has been found in the northernmost military fortifications of the Ottoman Empire.

\footnotetext{
${ }^{1}$ KАЗАКОВА 1962; 1963.

${ }^{2}$ ГУДИМЕНКО 1996: 10.

${ }^{3}$ ГУСАЧ 2006: 127-141; МАСЛОВСКИЙ 2010: 216; ГОНЧАРОВА 2012; 2019; ШИРОЧЕНКО 2013; КРАВЧЕНКО 2018: 122-178.
} 
This requires a sufficient series of specialist analyses (primarily concerning the chemical composition of the glazes and of the clay mass). It also requires the collection of a comparative databank from a vast territory that was once part of the Ottoman Empire.

\section{HISTORY OF THE «POLYCHROME MARBLE WARE»}

Before we proceed to the description of findings from the excavations in the territory of former Ottoman fortresses in the North-East Azov region, it is necessary to give a general description of the «Polychrome Marble Ware». This is termed in the literature variously: "Ceramics with marble-like paintings» ${ }^{4}$ " Marmurova ceramics»5 , «B5 Ware» ${ }^{6}$, «Marbled Ware(s) ${ }^{7}$, «Marble ceramics» ${ }^{8}$ and «Ebrulu seramikler» $»^{9}$. After the publication of J. Vroom on Aegean ceramics from the 7th to the 20th centuries, many researchers began to use the term «Polychrome Marble Ware» as had been suggested by her. ${ }^{10}$

«Polychrome Marble Ware» is a pottery tableware (plates, bowls and jugs) decorated with a particular type of under-glaze decoration, which is generally considered to imitate natural «stains» or "veins» on marble and is, therefore, called «marble décor» or «marble painting». The technique of applying this type of ornament to a surface of the vessel is quite original. A master applies large drops of liquid dye (coloured engobe) of one or more colours to a wet layer of white engobe primer and sets in motion the potter's wheel, on which the vessel sits, periodically changing the direction of its rotation. As a result, the dyes (coloured engobes) are randomly spread (slide) on the surface of the pottery, forming striking «stains" that look like veins on marble. This «marble» effect is often enhanced by the additional application of green dye (copper oxide) to form «blurring» spots or stripes under a layer of transparent lead glaze with a salad or yellowish tint. A Turkish name for this tableware ornamentation technique obviously comes from a similar paper painting technique: «ebru».

Medieval fashion for «Polychrome Marble Ware» originated in Northern Italy, where it was called «Ceramica Marmorizzata» and was produced for sale in many famous Italian cities (Faenza, Savona, Pisa and Florence), according to data from the 2 nd half of the $16^{\text {th }}$ century, ${ }^{11}$ and another dataset from the end of the $15^{\text {th }}$ century. ${ }^{12}$

\footnotetext{
${ }^{4}$ КОВАЯЬ 1998.

${ }^{5}$ БІЛЯЄВА 2012: 230.

${ }^{6}$ RICE 1930: 48-49.

${ }^{7}$ HAYES 1992: 274; ARMSTRONG \& GÜNSENIN 1995: 200.

${ }^{8}$ KAMADADZE 2016: 246-251.

${ }^{9}$ BARIŞTA 1998: 70.

${ }^{10}$ VROOM 2005: 165.

${ }^{11}$ VROOM 2005: 165; MOORE VALERI 2012: 11

${ }^{12}$ RICE 1930: 48; BAKIRTZIS 1980: 151.
} 


\section{TYPES AND FORMS OF «POLYCHROME MARBLE WARE» FROM THE OTTOMAN FORTRESS OF AZAK IN SOUTHERN RUSSIA (CERAMOLOGICAL STUDY)}

The peak of production took place at the end of the $16^{\text {th }}-17^{\text {th }}$ centuries. The popular forms of Italian pottery of this type were: hemispherical bowls, plates, dishes, bowls, one-handed jugs with a whisk in the form of a trefoil and «flasks» ${ }^{13}$ [FIGURES 5/1-2].

All «Marmorizzata ceramics» were red clay and belonged to a «Slip ware» category. There were three schemes of ornamentation of Italian vessels with coloured engobes: two-colour (red-white; black-white), three-colour (white-red-black; brown-green-black; white-brown-green; white-brown-black) and four-colour (red-white-brown-green). ${ }^{14}$ Normally marble decoration was applied only to the inner surface of open-shape vessels and the outer surface of closed-shape vessels. Northern Italy remained a major exporter of «Marmorizzata ceramics» to international markets until the $18^{\text {th }}$ century.

Italian traditions of «Polychrome Marble Ware» production spread throughout the Mediterranean and Black Sea regions, including a vast territory of the Ottoman Empire in the $17^{\text {th }}$ and $18^{\text {th }}$ centuries. Imitations of this tableware were found on the Aegean and Marmara Sea coasts, as well as in Europe.${ }^{15}$ In tribute to European fashion at the turn of the $17^{\text {th }}-18^{\text {th }}$ centuries, the production of "Polychrome Marble Ware" in Russia (in particular, in Moscow) and Ukraine (in Kiev and other pottery centers of the Middle Dnieper) began to be established, and remained in existence until the $19^{\text {th }}$ century ${ }^{16}$.

In the territory of the Ottoman Empire, the production of polychrome ware imitating Italian ceramics "Marmorizzata» appeared in the $17^{\text {th }}$ century and existed until the $19^{\text {th }}$ century ${ }^{17}$. But Ottoman samples of this tableware were externally different from the original Italian «Marmorizzata» ceramic products in terms of: the shape of the vessels, the composition and colour of the clay mass, the glazed coating and the very appearance of «marble» decoration. This can be well traced back to the remains of the vessels which, together with the Ottomans, entered the North-East Azov region in the $17^{\text {th }}$ to first third of the $18^{\text {th }}$ centuries, and was discovered during archaeological research of the Turkish fortress Azak [FIGURES 2-4].

\footnotetext{
${ }^{13}$ VROOM 2005: 164-165; MOORE VALERI 2012: 21, FIG.23; AMOURIC \& et AL. 1999.

${ }^{14}$ MOORE VALERI 2012: 17.

${ }^{15}$ VROOM 2005: 165.

${ }^{16}$ КОВАЛЬ 1998: 227-228; БІЛЯЕВА 2012: 231; ЧМИЛЬ 2013: 258.

${ }^{17}$ VROOM 2005: 165.
} 


\section{CLASSIFICATION «POLYCHROME MARBLE WARE« FROM THE OTTOMAN FORTRESS OF AZAK}

The bulk of the studied group of glazed ceramics from the territory ofAzak relate to dinnerware, where the vast majority are fragments of open-shape vessels $(93.7 \%$ of the total number of ceramics fragments).

\section{Open-Shape Vessels:}

\section{Plates.}

Among the open-shape vessels, the largest number of fragments are from plates (small and deep) with a ring-shaped pallet (more than 44 fragments), which in turn are morphologically divided into four subgroups:

\section{A. Small Plates with Wide Border.}

The height of the plates is about $4.0 \mathrm{~cm}$. They have a rounded, semi-oval rim in profile with diameter of $18.0-19.0 \mathrm{~cm}$, which merges with a wide, slightly bevelled inward border (width of the rim is 3.0-4.0 cm). The body is flattened and half-shaped. The ring-shaped pallet is low, narrow, truncated-conical or cylindrical, with a flat base (pallet diameter: 7.0-12.0 cm; pallet height: $0.5-0.6 \mathrm{~cm}$; width: $0.6-0.8 \mathrm{~cm}$ ). Seven of the Azov fragments belong to this subgroup. All plates are made of pliant brown clay (except one plate of beige clay) on a potter's wheel [FIGURES 2/1-2]. Only the inner surface is decorated, using two simple ornamental schemes:

Scheme $\mathbf{N}^{\circ}$. 1. Marble «stains» occupy the entire inner surface of the vessel [FIGURES 2/2]; Scheme $\mathbf{N}^{\circ}$.2. Wide vertical strips of underflow on the border and sides of the body, turning into marble «stains» at the bottom of the vessel [FIGURES 2/1].

The pattern is done with brown dye (engobe) on white engobe primer, in four cases with green dye in the form of amorphous spots and «stains». Both surfaces of the plates are covered with semi-transparent lead glaze in salad, yellow or yellow-salad colors; the outer surface is glazed directly on the ceramic. As a rule, the glaze is applied to the entire outer surface of the product, except for the bottom and inner side of the ringshaped pallet. The only exception is a single fragment of a plate found during excavations in 1978 onthe territory of the former Azak fortress. The entire outer surface of this plate was covered with a salad-coloured glaze, including the bottom ring pallet, which is very rare for vessels of this type [FIGURES 2/2].

There are some traces of the use of a clay tripod stand at the bottom of two plates when kiln firing the product. A peculiarity of one of the plates is the presence of two small, concentric, roller-shaped circles on the inner surface of its bottom

[FIGURES 2/ 1]. 


\section{TYPES AND FORMS OF «POLYCHROME MARBLE WARE» FROM THE OTTOMAN FORTRESS OF AZAK IN SOUTHERN RUSSIA (CERAMOLOGICAL STUDY)}

\section{B. Small Plates with a Narrow Border.}

The size of these vessels is noticeably smaller than the others (height - about $3.5 \mathrm{~cm}$, diameter of the rim $-15.0-16.0 \mathrm{~cm})$, so in our opinion it is appropriate to call them «small plates». They have a rectangular aureole that merges with a narrow $(1.4-1.5 \mathrm{~cm})$, inward-bevelled border. The plate body is flattened with a hemispherical shape. The pallet is ring-shaped, low, narrow, truncated-conical or subcylindrical, with a flat base (pallet height 0.6-0.7 cm; width 0.5-0.7 cm; diameter 6.0-8.0 cm). The plate sides gradually thicken from top to bottom $(0.2 \mathrm{~cm}$ to $0.9 \mathrm{~cm})$. According to the fairly large numberof fragments found (26 pieces), it was a very common type of dinnerware with marble decoration in Azak. Of these, eight fragments were light clay plates [FIGURES 2/8] and 18 fragments were brown clay plates [FIGURES 2/6-7, 9] made on a potter's wheel.

As with the plates of the first subgroup, two ornamental patterns can be traced in the decoration ( $\mathrm{N}^{\circ} .1$ and $\mathrm{N}^{\circ} .2$ ), with the second pattern somewhat dominant [FIGURES 2/7-8]. Only the inner surface of the plates is decorated. The ornamentation is applied with a brown dye (engobe) on a white engobe under a translucent lead glaze of green, salad and yellow salad, sometimes with a green tint in the form of amorphous spots and «stains«. Brown-clay plates have glaze on both sides, outer surface glazed directly on the ceramic body (except the base and inner part of the ring-shaped pallet on the bottom).For light clay plates, the glaze is applied to the inner side and only to the upper part of the outer side. There are traces of a clay tripod stand at the bottom of one of the plates.

\section{Deep Plates with a Narrow Border.}

Only 3 fragments of a single plate were found to belong to this subgroup. The corolla of the plate is rectangular in cross-section, with a flattened edge (the diameter of the rim is $21.0-22.0 \mathrm{~cm})$. The rim merges with a narrow $(1.5 \mathrm{~cm}$ ) border, curving strongly outward and inward. The plate body had a hemispherical shape. The plate is made of pinkish brown soft clay on a potter's wheel with no visible inclusions. The whole inner surface of the vessel is decorated with marble. The ornamentation is of brown «stains» on white primer with a green tint in the form of amorphous spots. Both surfaces of the plate are covered with translucent yellow-salad lead glaze, the outer surface being glazed directly on the ceramic [FIGURES 2/3-5].

\section{Deep Plates with No Border.}

The feature of this not very numerous subgroup of plates (8 fragments) is the lack of a border. The rim is straight and semi-oval in cross-section, with a rounded edge (the rim diameter is 19.0-20.0 cm), merging with the flattened half-spherical body walls [FIGURES 3/1-3]. The plates sat a low, narrow ring pallet that have not survived. The plates had thick sides $(0.5-0.8 \mathrm{~cm})$. They are made of light beige $(5$ pcs.) and brown $(3$ pcs.) clay thrown on a wheel. 
Scheme $N^{\circ} .2$ has been used for the decoration. The glaze is semi-transparent, lead, salad and yellow-salad colors. On brown-clay plates it is applied on both surfaces (on theouter surface, directly on the pottery), and on beige plates It appears on the inner and upper parts of the outer surface on white engobe.

\section{Bowls.}

This is a very small group in Azak. We were able to track only 8 rim fragments and body shards here, and there are no whole items [FIGURES 4/ 1-4]. All identified samples of bowls are brown-clay, made on a potter's wheel. The shape of the vessels is identical: a straight, semi-oval crown (15.0-16.0 cm in diameter) merging with a hemispherical body, and a low, narrow ring-shaped base. Theornamentation is applied to one of the surfaces - either internal [FIGURES 4/2] or external [FIGURES 4/1, 3-4]. Two patterns of ornamentation can be seen on the inner surface: $\mathrm{N}^{\circ} .1$ and $\mathrm{N}^{\circ} .2$.

Some of the bowls are decorated with marble «stains» on the outside. The ornamentation is applied with a brown dye (engobe) on a white engobe primer, sometimes with green spots under the transparent lead glaze of salad, lettuce yellow and green. Vessels with ornaments on the inner surface of the vessel have a decorfree outer surface in fourcases, without white primer; in two cases (in bowls with striped sides), white engobe is applied only to the top of the vessel.

\section{Unidentified Fragments.}

Twenty-two fragments of bottoms on ring-shaped bases and the sides of openshaped vessels decorated with marble ornaments are worthy of a separate description. It is difficult to determine what kind of vessels (plates or bowls) they belong to. Of these, six fragments (five bottoms and one body shard) belong to vessels made of light beige-coloured soft clay [FIGURES 3/4-5]. The remaining 16 fragments (nine bottoms and seven bodyshards) belong to brown clay vessels [FIGURES 3/6-8].

Fragments of light clay ceramics (6 pcs.) obviously belong to thick-walled plates on a low, narrow cylindrical ring-shaped pallet (pallet height 0.7-0.9 cm; width 0.7-0.8 cm; diameter $8.0-10.5 \mathrm{~cm}$; wall thickness $0.5-0.8 \mathrm{~cm}$ ). The marble decor is applied to the interior surface with a brown dye (engobe) on a white primer (sometimes with green spots) under a translucent lead glaze of green, salad or yellow-salad. The external surface of the vessels was covered with glaze, apparently only at the upper part. The inner side of the bottom of the three fragments is decorated with a small roller-shaped circle, in one case with a dot-shaped convexity in the center [FIGURES 3/4]. On the outer side of the bottom of one of the plates there is graffiti in the form of a sign resembling the letter «A» [FIGURES 3/4]. Technological features of the production can 


\section{TYPES AND FORMS OF «POLYCHROME MARBLE WARE» FROM THE OTTOMAN FORTRESS OF AZAK IN SOUTHERN RUSSIA (CERAMOLOGICAL STUDY)}

be seen from the remaining tripod fastening points on the inner side of the vessel bottom.

Brown-clay crockery is represented by nine fragments of donuts on similar ring pallets and seven fragments of body walls. Judging by the shape, size and wall thickness, most of the fragments also belong to plates (pallet height 0.7-0.8 cm; width 0.6-0.8 cm; diameter 8.0-10.0 cm). Three patterns of ornamentation can be traced: to the two patterns described above (scheme $\mathrm{N}^{\circ}$. 1-2) [FIGURES 3/4-7] a third scheme (scheme $\mathrm{N}^{\circ}$. 3) with «stains» and «splashes» was added [FIGURES 3/8]. The surface of one plate is completed with a relief flower rosette inscribed inside two roller-shaped concentric circles at the bottom of the vessel [FIGURES 3/8].

There is such a medallion with a five-petal flower rosette at the bottom of a «redclay» plate, found in the $17^{\text {th }}-18^{\text {th }}$ centuries during archaeological research of the medieval fortress Funa in the Crimea. The inner side of the plate is decorated with wide vertical stripes that turn into marble «stains» (scheme $\mathrm{N}^{\circ} .2$ ). The ornament is made of brown engobe on white primer under a layer of yellow-green glaze ${ }^{18}$.

The decoration on fragments of the bottoms of open-shape vessels from Azak is made in the standard way described above: brown dye (engobe) on white engobe primer, often with coloured green stripes and stains under a layer of translucent lead glaze in green, salad, yellow or yellow-salad. In almost all cases (except three), the entire outer surface of the vessels (except for the bottom and inner side of the ring pallet) is covered with the same glaze directly on the pottery. The bottoms of the three plate fragments are decorated with a small roller-shaped circle (diameter of circles - 3.0$4.0 \mathrm{~cm}$ ) with a point-shaped convexity in the center. Two concentric roll-shaped circles decorate the bottom of two more plates, which were obviously made in one ceramic center.

\section{Close-Shape Vessels:}

\section{Jugs.}

Only three fragments of the closed vessels decorated with marble ornaments were identified, two of which belong to one jug found on the territory of the Azak fortress in 1978. The jug had a low, narrow, cylindrical neck merging with a straight, semi-oval profiled rim (rim diameter is $7.0 \mathrm{~cm}$ ). The shoulders of the jug are short and smoothly rounded into a sub-shaped body. The lower part of the vessel has not been preserved. The handle is arched, vertical, narrow and oval in cross-section. The pitcher is made of brown pliant clay with a high lime content on a potter's wheel. The marble decoration, made ofbrown dye (engobe) on a white engobe primer, obviously covered its entire

\footnotetext{
${ }^{18}$ МЫЦ 1985: 7-9, FIG.82.
} 
outer surface. The glaze is translucent, lead and yellow salad-coloured, applied to both surfaces of the vessel, and directly on the pottery on the inner surface [FIGURES 4/6].

In 1962, a similar jug body fragment with marble decoration was found in Azov, its decoration of brown dye on white primer with green spots under semi-transparent salad glaze (on the inner side it is applied to the shard) ${ }^{19}$. The upper part of the body is additionally decorated with several thin cutting lines in the technique under-engobe engravement. The moulding mass is pliant, brown in colour, with rare lime dot inclusions [FIGURES 4/8].

\section{Jug Lids.}

The jugs had lids. A total of three lids of the same style were found on the territory of the Azak fortress: with a flat-hemispherical dome that goes into a disc and a button-like handle-holder. The two lids have almost identical dimensions (the height of the lids with a handle is $4.5 \mathrm{~cm}$, the diameter of the lids is $7.0-8.0 \mathrm{~cm}$ and the diameter of the handles is $1.2-1.5 \mathrm{~cm}$ ). They are made in the same ceramic center as the jug found at Azak in 1978. The pattern of ornamentation is similar to that of jars: marble «stains» on the outer surface [FIGURES 4/5, 7].

\section{OTTOMAN CENTERS OF «POLYCHROME MARBLE WARE» PRODUCTION}

The biggest difficulty in this study is the question of how to identify the ceramic centers that produced the «Polychrome Marble Ware» which came with the Ottomans in the $17^{\text {th }}$ and $18^{\text {th }}$ centuries into the fortress of Azak and the North-East Azov region. Visual observations allow us to identify at least four centers that produced this ceramics from light, predominantly beige, clay, and approximately five centers that produced the same «red clay» dishes. Of the total number of «Polychrome Marble Ware» fragments fromAzak fortress, the vast majority (61 fragments) belong to «red clay» or, more precisely, brown clay vessels. A significantly smaller number (18 fragments) are light clay vessels.

After studying the morphology, the peculiarities of ornamentation and glazing, and the composition of the moulding mass of the Ottoman «Polychrome Marble Ware» from the Azov Museum-Reserve, we were able to draw some preliminary conclusions about their centers of manufacture. In our opinion, open-shape light clay vessels (plates and small plates) were produced inthe Ottoman Empire, in roughly four ceramic centers:

Center $\mathbf{N}^{\circ}$. 1 It produced «Polychrome Marble Ware» made of light beige clay with a high lime content. There are nine such fragments. They belong to the plates and small plates of subgroup 1.2 and 1.4 according to our classification [FIGURES 3/1-2, 4].

\footnotetext{
${ }^{19}$ KАЗАКОВА 1963.
} 


\section{TYPES AND FORMS OF «POLYCHROME MARBLE WARE» FROM THE OTTOMAN FORTRESS OF AZAK IN SOUTHERN RUSSIA (CERAMOLOGICAL STUDY)}

A distinctive feature of the products of this center is the presence of a small roller-shaped circle onthe inner surface of the bottom with a dotted bulge in the center. There is graffiti at the bottom of one of these plates, but this is a single case [FIGURES 3/4]. The glaze is translucent, green and salad-coloured and is applied to the inside of the vessels over vertical stripes and marble dressings made with brown dye on white primer. Apparently, the outer side of the decor and glaze were applied only in the upper part ofthe plates.

Center $N^{\circ}$. 2 Represented by three fragments of plates and small plates of subgroups: 1.2 and 1.4. The dishes were made of similar clay, but with less lime in them. The small and deep plates of this center are decorated with vertical stripes on the inside of the rim and the body, which turn into marble «stains» at the bottom. The translucent salad oryellow-salad glaze covers the entire inner and upper part of the outer surface of the vessel [FIGURES 2/8; 3/3].

Center $\mathrm{N}^{\circ} .3$ The masters of center $\mathrm{N}^{\circ} .3$ produced their products from light beigecoloured pliant clay, which contains a small amount of lime and chamotte (dotted inclusions). There are five such fragments. They belong to the small plates of subgroup 1.2.The ornamentation is similar to that described above. The glaze is semi-transparent, yellow-salad, applied to the inner and upper parts of the outer surface of the vessel.

Center $\mathbf{N}^{\circ} .4$ It made plates with a marble decoration of light beige pliant clay, which contained organic material, but this burned out during firing, as evidenced by the remaining long, narrow pores on the outer surface. Only one fragment of the bottom has been preserved, on a low, narrow, circular tray of an Azak plate decorated with marble «stains « and covered with a layer of semi-transparent salad glaze on the inside and the same glaze on the outside, only on the top of the vessel [FIGURES 3/5].

Publications by Turkish researchers show that unglazed and glazed tableware (including marble decorations) made of light «white» clay, along with pottery made of «red» clay, were produced in two well-known ceramic centers in Istanbul during the Ottoman period-Eypsultan (Eyüpsultan) and The Tekfour Palace (Tekfur Sarayı). Scientists have found that «white« cookware has been produced here since Byzantine times $^{20}$. Eyüpsultan, the famous $17^{\text {th }}$ century traveller Evlia Chelebi, mentioned the pottery district of Istanbul in his notes. According to his information, «white» clay was brought to Eyüpsultan from such areas of Istanbul as Kığıthane and Sarıyer, and «red»

\footnotetext{
${ }^{20}$ BARIŞTA 2002: 156-159; YENIŞEHIRLIOČLU 2007: 359; YENIŞEHIRLIOČLU 2012: 78-79.
} 
clay from the Golden Horn (Haliç) and Kemerburgaz ${ }^{21}$. Researchers at the CNRS Ceramology Laboratory in Lyon, France, discovered through a series of chemical analyses that the «white» clay used in Eyüpsultan workshops was also used by potters from Tekfur Sarayı and other ceramic workshops in Istanbul. This clay is very similar to Byzantine clay and was brought from Bakırköy-Avcılar in Istanbul ${ }^{22}$.

Filiz Yenişehirlioğlu believes that bowls and plates with marble decoration «ebru» began to be produced in Eyüpsultan in the 17 $7^{\text {th }}$ century. She found the products of this Ottoman ceramic center among vessels excavated in Georgia and in the Sudak fortress in Crimea ${ }^{23}$. A more detailed review of her published findings from Sudak revealed that they have parallels in vessels from the Azak fortress, which we attribute to two different centers that produced light clay ceramics with a small content of lime (center $\mathrm{N}^{\circ} .2$ ) and organic inclusions (center $\mathrm{N}^{\circ}$. 4) in the molding mass. This may indicate that Eyüpsultan's potters produced their dishes (including plates with marble decoration) from «white» clay, which they were supplied with from various clays in Istanbul (Kığıthane, Sarıyer, Bakırköy-Avcılar and others). In addition, the products of different masters from the same large center could differ both morphologically (e.g. the shape and size of the pallet) and with special inclusions (e.g. organic) artificially added to the clay by individual potters.

Another decorative element characteristic of the Eyüpsultan light clay plates found in Sudak is the presence of two concentric roll-shaped circles at the bottom of one example and one roll-shaped circle with a convex central point in the bottom of another. A similar roller-shaped circle with no dot inside is present at the bottom of a plate from Azak (center $\mathrm{N}^{\circ} 4$ ). The same circle with a point-shaped convexity in the center is found at the bottom of other light clay plates (center $\mathrm{N}^{\circ} .1$ and center $\mathrm{N}^{\circ}$. 2) [FIGURES 3/4]. This means that the vessels we categorised as from centers № 1, 2 and 4 may have been manufactured in the same ceramic center - Eyüpsultan.

Örcün Barışta, who conducted excavations in the Eyüpsultan district of Istanbul in 1996-1998, in her article on the «marble» ceramics of this center, among others, provides an image of three fragments of light clay plate bottoms with roller-shaped circles. The inner surface of these plates is decorated with white-brown «stains» under a layer of translucent yellow-salad glaze ${ }^{24}$.

These publications by Turkish archaeologists allow us to conclude that Eyüpsultan potters made plates of «white» clay decorated with marble ornaments «ebru», which were often decorated with one of three types of roller circles on the inside of the bottom:

\footnotetext{
${ }^{21}$ YENIŞEHIRLIOČLU 2007: 359; YENIŞEHIRLIOČLU 2012: 79.

${ }^{22}$ YENIŞEHIRLIOČLU 2009: 630.

${ }^{23}$ YENIŞEHIRLIOČLU 2007: 361, fot.8.

${ }^{24}$ BARIŞTA 2002: 157, FIG. 1, 2.
} 
1) Two concentric circles;

2) One circle with a dotted bulge in the center;

3) One circle without a «dot» in the center.

Potters and many other ceramic centers, including Tekfur Sarayı, have obviously successfully used a similar scheme for the bottom of glazed plates. Unfortunately, we do not have samples of pottery produced in the workshops of Tekfur Sarayı to draw conclusions about whether this centre's pottery features among the assemblage from Azak. The well-known publications of Turkish researchers on excavations at Tekfur Sarayı do not yet clarify thisissue.

These findings are also confirmed through study of the «red clay tableware» with marble decoration from Azak, which in the $17^{\text {th }}-18^{\text {th }}$ centuries came to the North-East Azov region in much larger volumes than the light clay «marble» tableware. According to our observations, this tableware was produced in approximately five ceramic centers:

Center $\mathbf{N}^{\circ} .1$ It produced vessels of closed (jugs with lids) and open (plates, bowls) shape (15 fragments) from well-treated, pliant, dark brown and red-brown clay with a large admixture of lime (numerous dotted lime inclusions). The glaze is translucent, lettuce, yellow-salad and green, and was applied to both surfaces of the vessels. The white-brown striped marble and marble ornament is sometimes coloured with a green dye. Single-handed jugs are small in size, with a relatively narrow cylindrical neck and shoulder [FIGURES 4/6]. The lids of the jugs are of the same type, small in size, with a flattened hemispherical dome going into the disc and a button-shaped handle-holder [FIGURES 4/5]. Hemispherical bowls in some cases are decorated from the outside [FIGURES 4/1, 4], and in others from the inside [FIGURES 4/2]. Some of the plates belong to subgroups 1.1 [FIGURES 2/2], 1.2 and 1.4; other subgroups are undefined [FIGURES 3/6, 7]. The plates have a low, narrow circumferential, truncated-conical tray with an inner margin at the base. The inner side of the bottom of some of them is decorated with a roller-shaped circle with a dotted bulge in the center [FIGURES 3/7].

Center $\mathbf{N}^{\circ} .2$ Products (19 fragments) are made of soft clay of orange-brown or pinkbrown colors with a small admixture of lime. The glaze is translucent, salad, yellow and green in color and is present on both surfaces. The striped marble white-brown decor is in some cases coloured with green dye. All open-shape vessels are plates of subgroup 1.1 [FIGURES 2/1), 1.2 [FIGURES 2/7] and 1.4, as well as several indeterminate bottoms on a low, narrow ring-shaped cylindrical and truncated-conical pallet with an inner 
margin at the base [FIGURES 3/8] and one wall of the ceramic body. The fragments of plate bottoms show two concentric roller circles and the traces of a tripod stand [FIGURES 2/ 1]. The bottom of one of the plates is decorated with two concentric circles and a relief image of a floral rosette [FIGURES 3/8].

Center $\mathbf{N}^{\circ}$ 3. It produced jugs with lids [FIGURES 4/7-8] and plates of subgroup 1.3 [FIGURES 2/3-5] from pliant clay of orange-brown and pink-brown colors with insignificant lime and single inclusions of small grains of black quartz (five fragments). The glaze is salad and is applied to both surfaces. The decoration is of white- brown marble «stains « with green dye undertone. If the impurity of quartz is accidental, then we can assume that this ware was made in center $\mathbf{N}^{\circ} 2$.

Center $N^{\circ} .4$ The potters at this center produced plates with a marble decoration (17 fragments) of light brown pliant clay with little lime and sand admixture (mica glitter). The glaze is translucent, yellow, salad and green in colors and is applied to both surfaces of the vessels. The decoration includes white-brown stripes and marble «stains», sometimes with a green dye under colouring. The center's products only include fragments of open-shape vessels: bowls and plates of subgroup 1.2 and 1.4. Several fragments are undefined. At the bottom of the two plates there are roller-shaped circles, one of which has a «dot» in the center.

Center $\mathbf{N}^{\circ} .5$ Its products are very limited: only five fragments from four plates, two of which belongs to subgroup 1.2 [FIGURES 2/6,9). The dishes are made of light brown and orange-brown pliant clay with rare inclusions of lime and chamotte. The glaze is translucent, yellow-salad, applied to both surfaces, in one case obviously only to the inner surface. The decoration is of white-brown marble «stains» with a green tint. Visually, the fabric of the plates is similar to that used for mass glazed dishes in Crimean ceramic workshops. But the morphology and ornamentation of the vessels are similar to the products of the Ottoman workshops described above. Therefore, there is the suggestion that Crimean potters imitated fashionable Ottoman «marble« tableware brought to the Crimea and North-Eastern Azov region from Anatolia and the coast of Marmara Sea in the $17^{\text {th }}-18^{\text {th }}$ centuries.

In addition to Eyüpsultan and Tekfur Sarayı's «Polychrome Marble Ware» ceramic workshops in Istanbul, «red» clay was used in the $17^{\text {th }}$ and $18^{\text {th }}$ centuries to produce pottery from Çanakkale, Ganos (Hoşköy), Didymoteichon (Dimetoka) and obviously other Ottoman settlements ${ }^{25}$. Before excavations at Eyüpsultan, it was believed that the

\footnotetext{
${ }^{25}$ BAKIRTZIS 1980: 147-195; HAYES 1992: 276; ARMSTRONG \& GÜNSENIN 1995: 180; BARIŞTA 1998: 71; BARIŞTA 2002: 158-159; YENIŞEHIRLIOČLU 2007: 359-361; YENIŞEHIRLIOČLU 2009: 630; FRANÇOIS \& ERSOY 2011: 388, FIG.10-12.
} 


\section{TYPES AND FORMS OF «POLYCHROME MARBLE WARE» FROM THE OTTOMAN FORTRESS OF AZAK IN SOUTHERN RUSSIA (CERAMOLOGICAL STUDY)}

«Polychrome Marble Ware» was only produced at Didymoteichon ${ }^{26}$. Archaeological research in Ganos confirmed the presence of the local «red» clay «Polychrome Marble Ware» ${ }^{27}$. These excavations have revealed that the clay of Ganos and Didymoteichon products is very similar: red-brown, with a small admixture of lime, which, according to scientists, indicates that one place for its extraction was the clays on the coast of the Sea of Marmara. For this reason, Ganos and Didymoteichon products are often confused. For example, in the opinion of P. Armstrong and N. Günsenin, the remnants of Ganosdishes excavated at Saraçhane in Istanbul were mistakenlyattributed by J.W. Hayes to the Didymoteichon ceramics (Ware $\mathrm{P})^{28}$.

Greek researcher $\mathrm{Ch}$. Bakirtzis ${ }^{29}$ noticed the relief rings at the bottom of glazed plates from Didymoteichon. Similar concentric circles are found at the bottom of glazed plates (including those with marble decor) produced in the $17^{\text {th }}-19^{\text {th }}$ centuries at the Çanakkale ceramic center ${ }^{30}$. According to J.W. Hayes, this center's products are very similar to Didymoteichon pottery, but differ in being a darker, richer red clay colour ${ }^{31}$. The similarity between Çanakkale and Didymoteichon ceramics is also indicated by G. Öney, assuming that Didymoteichon produced dishes very similar to Çanakkale (or vice versa) $)^{32}$. The ceramic centers of Eyüpsultan and Tekfur Sarayı in Istanbul, as we mentioned earlier, produced «red clay tableware» from the raw materials extracted from the Golden Horn and Kemerburgaz clays. However, we do not yet have more detailed information about the composition of this raw material.

Thus, based on data from international researchers, it is possible to make suggestions about the production centers for the Ottoman «marble» ceramics which entered the Turkish fortress of Azak in the $17^{\text {th }}-18^{\text {th }}$ centuries with the military contingent. The findings of light clay plates with marble decoration from the Sudak fortress in Crimea, which were found by Turkish explorer F. Yenişehirlioğlu, are a reference point. F. Yenişehirlioğlu referred to the products of the Eyüpsultan ceramic center in Istanbul ${ }^{33}$, while the remnants of similar plates made of light beige clay with a slight admixture of lime (center $\mathrm{N}^{\circ} .2$ according to our classification) and organic admixture (center $\mathrm{N}^{\circ} .4$ ) from the excavations in Azak most likely come from the same center. There are the same embossed circles (in different variants: double and single) at the bottom of the $\mathrm{A} \mathrm{z} \mathrm{a} \mathrm{k}$ plates as on the plates found at Eyüpsultan ${ }^{34}$.

\footnotetext{
${ }^{26}$ YENIŞEHIRLIOČLU 2012: 84.

${ }^{27}$ ARMSTRONG \& GÜNSENIN 1995: 198.

${ }^{28}$ HAYES 1992: 276; ARMSTRONG \& GÜNSENIN 1995: 180.

${ }^{29}$ BAKIRTZIS 1980, FIG.26, 27, 29b.

${ }^{30}$ DOČER 2009: 32-33, 45, TAB. 3.

${ }^{31}$ HAYES 1992: 276.

${ }^{32}$ ÖNEY 2007: 369.

${ }^{33}$ YENIŞEHIRLIOČLU 2007: 361, fot. 8.

${ }^{34}$ BARIŞTA 1998: 71, fot.103; BARIŞTA 2002: 157, fot.1, 3.
} 
Since potters of Eyüpsultan and Tekfur Sarayı used the same clay from Istanbul, as well as similar surface design techniques for their ceramics, the products of these centers must be very similar. It is possible that among the fragments of marble decor crockery from Turkish fortress of Azak in North-East Azov region there are products from the Tekfur Sarayı workshops.

In our opinion, the «marble» plates of Azak made of pliant clay in orange-brown and pink-brown with a small amount of lime, which have double embossed rings onthe bottom (center NO. 2) [FIGURES 2/1, 3/8], probably come from the Didymoteichon or Ganos ceramic workshops, or both, which had the same raw material base on the coast of the Sea of Marmara and similar clay products. The low, narrow circular pallet of these plates has an inner margin on its base similar to those of Didymoteichon, which J.W. Hayes described in his study ${ }^{35}$.

The fragments of the plate and the jug we assigned to center NO. 3 [FIGURES 2/3- 5; 4/7-8] were presumably also made by Didymoteichon or Ganos potters. However, the presence of single quartz inclusions in the moulding mass of these vessels may also indicate that they were produced in Çanakkale. And finally, the products of center No. 5, in our opinion, are an imitation of the Ottoman «Polychrome Marble Ware» by the Crimean pottery workshops [FIGURES 2/6, 9]. Defining the remaining centers is still very problematic.

\section{DATING «POLYCHROME MARBLE WARE» FROM THE OTTOMAN FORTRESS OF AZAK}

Azak Ottoman fortress has a longer history. In 1475, the troops of the Turkish Sultan Mehmed II the Conqueror captured the stone castle of the Italian colony Tan at the mouth of the Don, turning it into the northernmost fortification of the Ottoman Empire - Azak fortress. Turkish domination lasted here until 1696, when the fortress was conquered by the army of the Russian Tsar Peter the Great. In 1712, the Ottomans returned to Azak, which again fell back to them under the terms of the peace treaty after the unsuccessful Prut campaign of Peter the Great in 1711. In 1736, Turkish Azak was reconquered by the Russian army of Tsarina Anna Ioannovna. The last period of the existence of the Ottoman Azak fortress dates back to 1712-1736.

Despite such a rich history, the findings of the «Polychrome Marble Ware» from the excavations of Azak fortress come from a restricted cultural layer of the end of the 17th century To the first third of the $18^{\text {th }}$ century.

\footnotetext{
${ }^{35}$ HAYES 1992: 276-277.
} 


\section{TYPES AND FORMS OF «POLYCHROME MARBLE WARE» FROM THE OTTOMAN FORTRESS OF AZAK IN SOUTHERN RUSSIA (CERAMOLOGICAL STUDY)}

This pottery is similar to the pottery from the fortress of Sed-Islam, built by the Ottomans on the neighboring branch of the Don River - the Dead Donets River - in 1660. The year 1741 is known from written sources for thedestruction of the Turkish Sed-Islam fortress under the Treaty of Belgrade (1739). Both «Turkish» (1660-1696; 1712-1736) and «Russian» (1669-1711; 1736-1741) periods of the fortress are known due to its transition from hand to hand during the three Russian- Turkish wars of 1686-1699, 1710-1713 and 1735-1739 ${ }^{36}$. Thus, the existence of «Polychrome Marble Ware» in Sed-Islam is divided into two narrow time periods, defined by two «Turkish" periods in its history - from 1660 to 1696 and from 1712 to 1736.

Unfortunately, large-scale fortification works in Azov, which unfolded by order of Peter the Great at the turn of the $17^{\text {th }}-18^{\text {th }}$ centuries, brought a lot of ambiguity to the stratigraphy of this archaeological monument. However, research by Azov archaeologists in recent years on the territory of Turkish Azak bring more and more new findings, which directly or indirectly confirm the validity of the initial dating of the Ottoman «Polychrome Marble Ware» - not before the $17^{\text {th }}$ century and not later than $1736^{37}$.

Archaeological findings of «Polychrome Marble Ware» in the territories that were formerly part of the vast Ottoman Empire, as well as in the adjacent lands, generally date back to the same time - the $17^{\text {th }}-18^{\text {th }}$ centuries. Fragments of «Polychrome Marble Ware» have been discovered during archaeological research of former Ottoman fortresses and their surroundings: Akkerman and Kamenets-Podolsky in Ukraine ${ }^{38}$ [FIGURES 5/5], Balaklava, Sudak, Mangup, Funa, Arabat in Crimea ${ }^{39}$, Gonio, Batumi and Narikala in Georgia ${ }^{40}$ [FIGURES 5/3-4]. They were also found during excavations in Romania ${ }^{41}$, Hungary ${ }^{42}$, and the Taman Peninsula in Russia ${ }^{43}$ [FIGURES 5/7]. There is also reference to the discovery of «Polychrome Marble Ware» during excavations in Partenit ${ }^{44}$ and the Çufut Qale fortress in the Crimea, in Kiev in Ukraine ${ }^{45}$, etc.

\footnotetext{
${ }^{36}$ ДОНСКІЯ ДЕЛА 1917: 730-731; ЧЕЛЕБИ 1979: 208-212.

${ }^{37}$ ГУСАЧ 2006: 134, 137; МАСЛОВСКИЙ 2010: 216; КРАВЧЕНКО 2018: 124-159; ГОНЧАРОВА 2019: 95-98, etc.

${ }^{38}$ БІЛЯЄВА 2012: 230-231, FIG.95, 115; СТРОЦЕНЬ \& et AL. 2015-2016: 18-19.

${ }^{39}$ ДАНИЛЕНКО \& РОМАНЧУК 1969: 126, ТАВ. 5, FIG. 49-50; МЫЦ 1985: 8-9, FIG. 82; YENIŞEHIRLIOČLU 2007: 356, fot. 8; ГЕРЦЕН \& КОЛТУХОВ 2009: 154-155, FIG. $13,8$.

${ }^{40}$ KAMADADZE 2016: 250-251.

${ }^{41}$ VOINEA et AL. 2016, FIG.17/1-3, FIG.20/ 7-8).

${ }^{42}$ ATTILA 2016: 291, TAB. 2, 3 a-c.

${ }^{43}$ ГОРОШНИКОВ \& КЛАДЧЕНКО 2015: 25, FIG.3, 14; ЗИЛИВИНСКАЯ 2016: 160-183, FIG.2730, 2798, 2936.

${ }^{44}$ АЛЯДИНОВА 2015: 461, FIG.16, 49.

${ }^{45}$ ЧМИЛЬ 2013: 258.
} 
In addition to the aforementioned Istanbul findings, the remains of «Polychrome Marble Ware» of the $17^{\text {th }}$ and $18^{\text {th }}$ centuries have been found in modern Turkey as well, during archaeological research on the Ottoman fortresses of Bitlis ${ }^{46}$, Sham ${ }^{47}$, Enes ${ }^{48}$, Izmir $^{49}$,Tyre (Kutu Khan) ${ }^{50}$ and others [FIGURES 5/6, 8-9].

\section{CONCLUSION}

Summing up our research, it should be noted that in the $17^{\text {th }}$ to the first third of the $18^{\text {th }}$ centuries, small quantities (a total of 79 fragments over fifty years of excavation) of «Polychrome Marble Ware» were brought in to the Turkish fortress of Azak with the military contingent and through traders. These vessels were produced in various ceramic centers of the Ottoman Empire. The small volumes of such tableware supplied to North-East Azov region testify to its high cost, due to the great popularity associated with the medieval fashion for Italian «Marmorizzata» ceramics and its Ottoman imitations, as well as to the significant distance between the Azak fortress and the ceramic centers where the Ottoman «Polychrome Marble Ware» was produced.

The main group of vessels from Azak (93.7\%) consists of fragments of open-shape containers - bowls and plates, which we divided into 4 subgroups by morphological features. The remains of the closed-shaped vessels are isolated. These arefragments of small jugs (2.5\%) with lids (3.8\%).

There are many more «red-clay» products with marble ornaments than light clay products (77.2\% red-clay; $22.8 \%$ light-clay). Among light-clay tableware vessels, only open forms are present, mainly plates. One of these plates has graffiti on the outside of the bottom. The assortment of «red-clay« products by Ottomanpotters is more diverse bowls, plates, and jugs and their lids.

In the «Polychrome Marble Ware» ornamentation from the Turkish fortress of Azak, we can trace 3 main schemes:

1) marble «stains», which occupy the entire outer surface of the product (bowls, jugs, lids) or the entire inner surface of the product (bowls, plates);

2) wide vertical stripes passing into marble «stains» on the inner side of the vessel (only on plates and bowls).

3) decor in the form of splash marks with marble «stains».

\footnotetext{
${ }^{46}$ BAŞ 2012: 117, kat.5.4.

${ }^{47}$ FRANÇOIS 2012: 504, pl. 5/3.

${ }^{48}$ BAŞARAN 2001: 382, res.5.

${ }^{49}$ DOČER 2009: 45, TAB. 3 b, d; GÖK 2015: 67, tab.2.

${ }^{50}$ UÇAR 2018: 4-5.
} 


\section{TYPES AND FORMS OF «POLYCHROME MARBLE WARE» FROM THE OTTOMAN FORTRESS OF AZAK IN SOUTHERN RUSSIA (CERAMOLOGICAL STUDY)}

In all cases, the decoration is made with white and brown engobe, sometimes with a greendye. An additional element in plate decoration is often a roller-shaped circle in the centre of the inner surface of the bottom (twin and single, with a convex «dot» in the center). As this technique was developed, masters of many Ottoman ceramic centers evidently designed their products with such relief rings.

The glaze used in Ottoman tableware with marble decoration is lead, semitransparent, yellow, lettuce, salad and green, often of rather poor quality (with undissolved dye particles). In «red-clay» vessels, both surfaces are covered with it, except for the inside of the pallet and bottom of the plates. However, there are rare instances of plates where both surfaces are completely glazed. In light-clay plates, the glaze is usually applied to the inside and top of the outer surface. The technological details of plate production are often traced as tripod marks on the inner side of the bottom.

Visual observations of the composition of the fabric, ornamentation and surface design of «Polychrome Marble Ware» from Azak allowed us to conditionally divide them into several groups according to proposed production centers (4 groups for light-clay vessels, 5 groups for «red-clay» vessels). Based on the research results of international scientists (and primarily Turkish archaeologists), we attempted to identify production centers for these ceramics. Our preliminary scheme (which obviously requires laboratory testing), suggests such centers could be Eyüpsultan and Tekfur Sarayı in Istanbul, as well as Didymoteichon (tour - Dimetoca) and Ganos (tour - Hosköy) on the coast of the Sea of Marmara. Products from Çhanakkale and other ceramic centers in the Ottoman Empire are als o likely to be among the assemblage. At this stage of research, it is not yet possible to define the production centers further.

\section{HOW TO CITE}

Khalil, W \& Gusach,I « Types and Forms of «Polychrome Marble Ware» from the Ottoman Fortress of Azak in Southern Russia(Ceramological Research)» Journal of the General Union of Arab Archaeologists, vol. 6/1, 2021. Doi: 10.21608/JGUAA2.2021.54530.1045. wam00@fayoum.edu.eg ; irina_gusach@mail.ru 


\section{BIBLIOGRAPHY}

АЛЯДИНОВА, Д.Ю.: «Керамика османского времени из раскопок Партенита« («Ottoman ceramics from Partenit excavations»), В: Древняя и средневековая Таврика, Археологический альманах №32 (In Ancient and medieval Taurica, Archaeological Almanac № 32), Киев 2015, 452-480.

БІЛЯЕВА, С.: Слов'янські та тюркські світи в Україні (Slavic and Turkic communities in Ukraine), Київ: Університет «Україна« 2012.

ГЕРЦЕН, А. \& КОЛТУХОВ, С.: «Археологические работы в Арабатской крепости«, В: Северное $и$ Западное Причерноморье в античную эпоху и средневековье («Archaeological Works in the Arabatskaya Fortress", In Northern and Western Black Sea Region in the Ancient Age and Middle Ages), Симферополь 2009, 144-172.

ГОНЧАРОВА, С.М.: Отчет об археологических раскопках на территории 2. Азова в 2011 году, т.1 (Archeological researches in Azov in 2011, vol.1), Азов 2012.

ГОНЧАРОВА, С.М.: Отчет об археологических раскопках на территории г. Азова Ростовской области в 2012-2013 z2., т. 2, 4 (Archeological researches in Azov, Rostov region in 2012-2013, vols. 2, 4), Азов 2019.

ГОРОШНИКОВ, А.А. \& КААДЧЕНКО, О.В.: «Керамика турецкого времени поселения «Волна-12« на Тамани«, В: Крым в войнах России, Материалы Всероссийской научной конференциии, Ростов-наДону, 19-21 октября 2015 г. («Ceramics of Turkish time settlement «Wave-12« on Taman«, In Crimea in the wars of Russia, Materials of the All-Russian Scientific Conference, Rostov-on-Don, 19-21 October 2015), Ростов-на-Дону: издательство ЮНЦ РАН 2015, 20-25.

ГУДИМЕНКО, И.В.: Отчет о спасательных археологических раскопках в г.Азове по ул. Яенинградской, 29 в 1994 zody (The report on the rescue archeological excavations in Azov, in 29 Leningradskaya St. in 1994), Азов 1996.

ГУСАЧ, И.Р.: «Археологические исследования на территории турецкой крепости Азак«, В: Историко-археологические исследования в Азове и на Нижнем Дону в 2004 г., вып. 21 («ТТе archeological researches on the territory of the Turkish fortress Azak«, In Historical and Archaeological Research in Azov and the Lower Don in 2004, issue 21), Азов 2006, 127-141.

ДАНИЛЕНКО, В.Н. \& РОМАНЧУК, А.И.: «Поливная керамика Мангупа«, В: Античная древность и Средние века 6, Ученые записки УрГУ, Серия историческая, вып.17 («Glazed Ceramics of Mangup«, In Ancient Antiquity and the Middle Ages 6, Scientists' Notes of Ural State University, Historical series, issue 17), Свердловск 1969, 116-138.

Донскія дела, Т. XXXIV, Кн. 5. (Don affairs, T. XXXIV, Book 5), Петроград: типография Министерства земледелия 1917.

ЗИЯИВИНСКАЯ, Э.Д.: Отчет о раскопках поселения и могильника "Соленый-2" в Темрюкском районе Краснодарского крал в 2016 году, т.1, 12 (Report on excavations of the Salty-2 settlement and cemetery in the Temryuk District of the Krasnodar Region in 2016, vol.1, 12), Санкт-Петербург 2016.

КАЗАКОВА, А.М.: Отчет о работах, проведенных Азовским историко-краеведческим музеем в ходе наблюдения за земляныли работами в г. Азове с сентября 1961 году (The report on the works of Azov Museum-Reserve during the observations of the excavation works in Azov since September 1961), Азов 1962.

КАЗАКОВА, Л.М.: Отчет об археологических работах музея в г. Азове в 1962 2. (The report on the works of Azov Museum-Reserve during the observations of the excavation works in Azov in 1962), Азов 1963.

КОВАЯЬ, В.Ю.: «Позднесредневековая гдазурованная керамика с мраморовидной росписью«, В: Тверь, тверская земля и сопредельные территории в эпоху средневековья, вып.3 («Late Medieval Glazed Ceramics with Marble Paintings", In Tver, Tver Land and Neighbouring Territories in the Middle Ages, issue 3), Тверь 1998, 222-229. 


\section{TYPES AND FORMS OF «POLYCHROME MARBLE WARE» FROM THE OTTOMAN FORTRESS OF AZAK IN SOUTHERN RUSSIA (CERAMOLOGICAL STUDY)}

КРАВЧЕНКО, С.А.: «Археологические исследования в г. Азове и Азовском районе в 2015 году« В: Историко-археологичекие исследования в Азове и на Нижнем Дону в 2015-2016 г2., вып.30 («Archaeological research in Azov and Azov district in 2015«, In Historical and Archaeological Research in Azov and the Lower Don in 2015-2016, issue 30), Азов 2018, 122-178.

МАСАОВСКИЙ, А.Н.: «Археологические исследования в городе Азове и Азовском районе в 20072008 гг.«, В: Историко-археологические исследования в Азове и на Нижнем Дону в 2007-2008 г2., вып.24 («Archaeological research in Azov and Azov district in 2007-2008«, In Historical and Archaeological Research in Azov and the Lower Don in 2007-2008, issue 24), Азов 2010, 182-242.

МЫЦ, Б.А.: Отчет об археологических исследованиях средневековых укреплений Алустон и Фуна в 1985 zody (Report on the Archaeological Research of the Medieval Fortifications Of Aluston And Funa in 1985), Симферополь 1985.

СТРОЦЕНЬ, Б.С., НЕЧИТАЙЛО, П.О., ПАШКОВЬСКИЙ, О.А., ПЕФТІЦЬ, Д.М. \& НЕЧИТАЙЛО, А.О.: Звіт про пам'яткоохоронні дослідження на території Національного історико архітектурного заповідника по вулиці Довга, 2/11 м. Кам'янець-Подільський Хмельницькой області у 2015 році (Repоrt on Monument and Conservation Studies on the Territory of the National Historical and Architectural Reserve at 2/11 Dolgaya Street in Kamyanets-Podilsky Khmelnitsky Region in 2015) Кам'янець-Подідьський 20152016.

ЧЕЛЕБИ, Э.: Книга путешествия. Извлечения из сочинения турецъкого путешественника XVII в., вып.2, Земли Северного Кавказа, Поволжья и Подонья (Book of Travel. Extracts from the work of the Turkish traveler of the XVII century, issue 2, Lands of the North Caucasus, Volga Region and the Don Region), Москва: Наука 1979.

ЧМИЯЬ, А.В.: «Один из видов росписи под поливой XVII-XVIII вв.«, В: Могилянські читання 2012 («One of the Types of Paintings Under Glaze of the XVII-XVIII Centuries«, In Mogilian readings 2012), Київ 2013, 256-260.

ШИРОЧЕНКО, Э.Б.: Отчет о спасательных археологических раскопках городища и могильника Азака в 2. Азове Ростовской области в 2009 году, т.1 (Report on the rescue archeological Excavations of The Ancient Settlement and Azak Cemetery in Azov, Rostov Region in 2009, vol.1) Азов 2013.

AMOURIC, H., RICHEZ, F. \& VALLAURI, L.: Vingt mille ports sous les mers. Voyages extraordinaires. Editions Édisud. Musée d'Istres (27 mai - 28 novembre 1999). Aix-en-Provence: Édisud 1999.

ARMSTRONG, P. \& GÜNSENIN, N.: «Glazed pottery production at Ganos«, In Anatolia Antiqua. Eski Anadolu 3, Paris: Institut Français d'ètudes Anatoliennes d'Istanbul 1995, 179-201.

ATTILA, G.: «16-18. Szàzadi leletek a szekszàrdi török palànkvàr környezetéből«, In A Wosinsky Mór Múseum Évkönyve 38, Szekszárd 2016, 285-327.

BAŞARAN, S.: Enez (Ainos) 1999 Yılı Kazı Çalışmaları, 22. Kazı Sonuçları Toplantısı, C.2, Ankara: Kültür Bakanlığı Yayınları 2001, 371-386.

BAŞ, G.: Bitlis Kalesi Kazısı Sırlı Seramikleri, Ankara: PEGEM Akademi Yayınları 2012.

BAKIRTZIS, Ch.: «Didymoteichon: un centre de cèramique post-byzantine«, In Balkan Studies, vol. 21, №1, Thessaloniki 1980, 147-195.

BARIŞTA, H.Ö.: Türk el sanatları, ilaveli 2, Ankara: Kültür Bakanlığı 1998.

BARIŞTA, H.Ö.: «Istanbul Eyüpsultan seramiklery», In Uluslarası Dördncu Türk Kültürü Kongresı, Ankara 1999, 85-93.

BARIŞTA, H.Ö.: «Eyüp Sultan'dan Ebru Desenli Seramik ve Çiniler«, In Eyüp Sultan Sempozyumu III, Eyüpsultan Belediyesi, Istanbul 2002, 156-163. 
BLAKE, H.: «Pottery exported from Northwest Italy between 1450 and 1830: Savona, Albisola, Genoa, Pisa and Montelupo«, In Archaeology and Italian Society, Prehistoruc, Roman and Medieval Studies, BAR International Series, vol.102, Oxford 1981, 99-124.

DOĞER, L.: İzmir Agorası Kazılarından 17.-19. Yüzyıl Seramik Buluntuları Üzerine Bazı Gözlemler, Sanat Tarihi Dergisi, Sayı XVII/1, Izmir 2009, 23-54.

FINDIK, N.Ö.: «Osmanlı Devri Seramik Sanatı«, In Türkler, Gazi Üniversitesi Fen-Edebiyat Fakültesi, Türkiye 2017, 375-384, https://www.altayli.net/osmanli-devri-seramik-sanati.html.

FRANÇOIS, V. \& ERSOY, A.: «Fragment d'histoire: la vaissele de terre dans une maison de Smyrne ua XVIII es.«, In Bulletin de correspondence hellenique, vol.135, livraison 1, 2011, 377-419.

FRANÇOIS, V.: «Objets du quotidien à Damas à l'époque ottoman«, In Bulletin d'études orientales 64 , 2012, 475-506.

GÖK, S.: «İzmir'in Ticari Yaşamında Osmanlı ve Avrupa Seramiklerinin Yeri, Smyrna«, In İzmir Kazı ve Araştırmaları I, Çalıştay Bildirileri, İstanbul: Ege Yayınları 2015, 61-78.

HAYES, J.W.: Excavations at Saraçhane in Istanbul, vol.2, Oxford (Princeton University Press) 1992.

KAMADADZE, K.: «Marble« Seramics from the Monuments of South-West Georgia«, In South-West Georgia (history, archaeology), International Scientific Conference materials, VI, Tbilisi 2016, 246-251.

MOORE VALERY, A.: «Marbleized pottery in Tuscany (1550-1650)«, In Medieval Ceramics, Journal of the Medieval Pottery Research Group, vol.33, 2012, 10-23.

ÖNEY, G.: Türk Devri Çanakkale Seramikleri, Ankara: Çanakkale Seramik Fabrikaları A.Ş. Yayınları 1971.

ÖNEY, G. (ed.): «Çanakkale Seramikleri«, In Anadolu'da Türk Devri Çini ve Seramik Sanatı, Ankara: Kültür ve Turizm Bakanlığı Yayinları 2007, 365-375.

RICE, D.T: The Bizantine Glazed Pottery, London 1930.

UÇAR, H. \& UÇAR, A.: «Tire Kutu Han Kazısı Beylikler Ve Osmanlı Dönemi Seramikleri«, In Sanat Tarihi Dergisi, XXVII, 1 Nisan /April 2018, 2018, 1-33.

VOINEA, V.M., SZMONIEWSKY, B. SZ., POPESCU, A., MOTOTOLEA, A. \& FLOREA, M.: «The rural landscape in Dobruja in the Ottoman period, New discoveries from Cheia - Pazvant sites, county Constanta, Romania«, In Journal of Aegean and Balkan Studies, vol.2 (2016-1), issue 3, Izmir 2016, 155200.

VROOM, J.: «Polychrome Marbled Ware«, In Byzantine to modern pottery in the Aegean (7th to 20 ${ }^{\text {th }}$ century), An introduction and field guide, Netherlands Utrecht: Parnassus Press 2005, 164-165.

YENIŞEHIRLIOĞLU, F.: «Tekfur sarayi çini fırınları kazısı 1995-2001«, In 24. Kazı sonuçları toplantısı, 1. Cilt (27-31 Mayıs 2002), Kültür Bakanlığı Dösimm Basımevi, Ankara 2003, 329-344.

YENIŞEHIRLIOĞLU, F. (ed.): «Tekfur Sarayı Çinileri ve Eyüp Çömlekçiliği«, In Anadolu'da Türk Devri Çini ve Seramik Sanatı, Istanbul: Kültür ve Turizm Bakanlığı Yayinları 2007, 349-361.

YENIŞEHIRLIOĞLU, F.: «Les fours et la production des céramiques du Palais de Tekfur a Istanbul «, In Actas del VIII Congreso International de Cerámica Medieval, Ciudad Real, vol. 2, 2009, 617-632.

YENIŞEHIRLIOĞLU, F.Ç.: «Istanbul Arkeolojisi ve Çini, Seramik Üretim Merkezleri«, In Istanbul Araştırmaları Yillı̆̆l, I, Istanbul 2012, 77-99. 


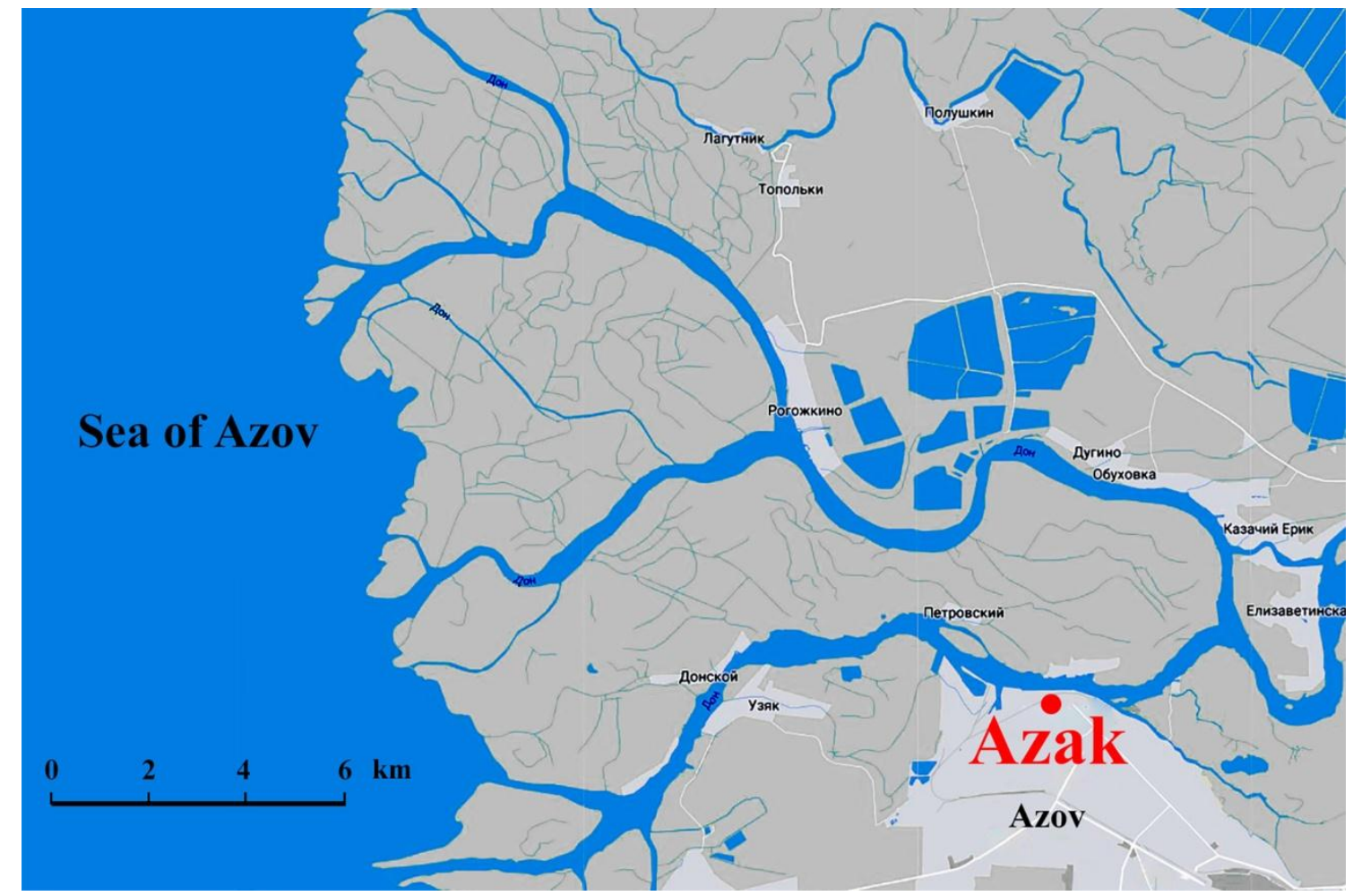

[FIGURE 1]: Location of the Ottoman fortress of Azak in the North-Eastern Azov region, Southern Russia, Https://www.google.com/maps/@47.170804,39.4282221,11.54z 


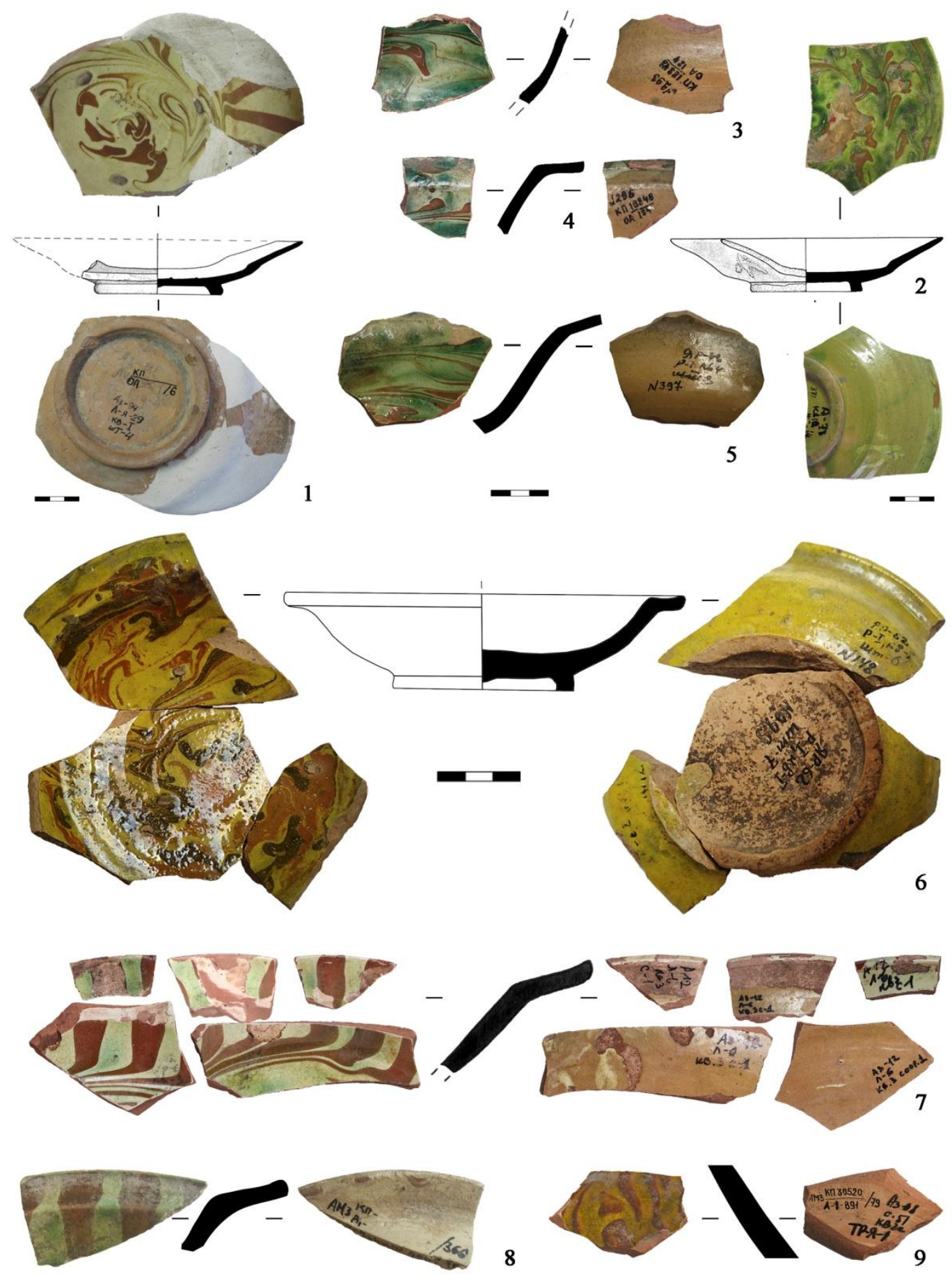

[FIGURE 2]:. «Polychrome Marble Ware» $\left(17^{\text {th }}-18^{\text {th }}\right.$ centuries) from the Ottoman fortress of Azak $\left(\mathrm{N}^{\mathrm{o}_{\mathrm{s}}} 1-\right.$ 9). Open-shape vessels: Group 1. Plates: $\mathrm{N}^{\mathrm{o}_{\mathrm{s}}} 1,2$ - subgroup 1.1; $\mathrm{N}^{\mathrm{o}_{\mathrm{s}}}$. 3-5 - subgroup 1.3; $\mathrm{N}^{\mathrm{o}_{\mathrm{s}}}$. 6-9 subgroup 1.2. From the collection of the Azov Museum-Reserve (Azov).

Photos by IRINA GUSACH, 2020. 

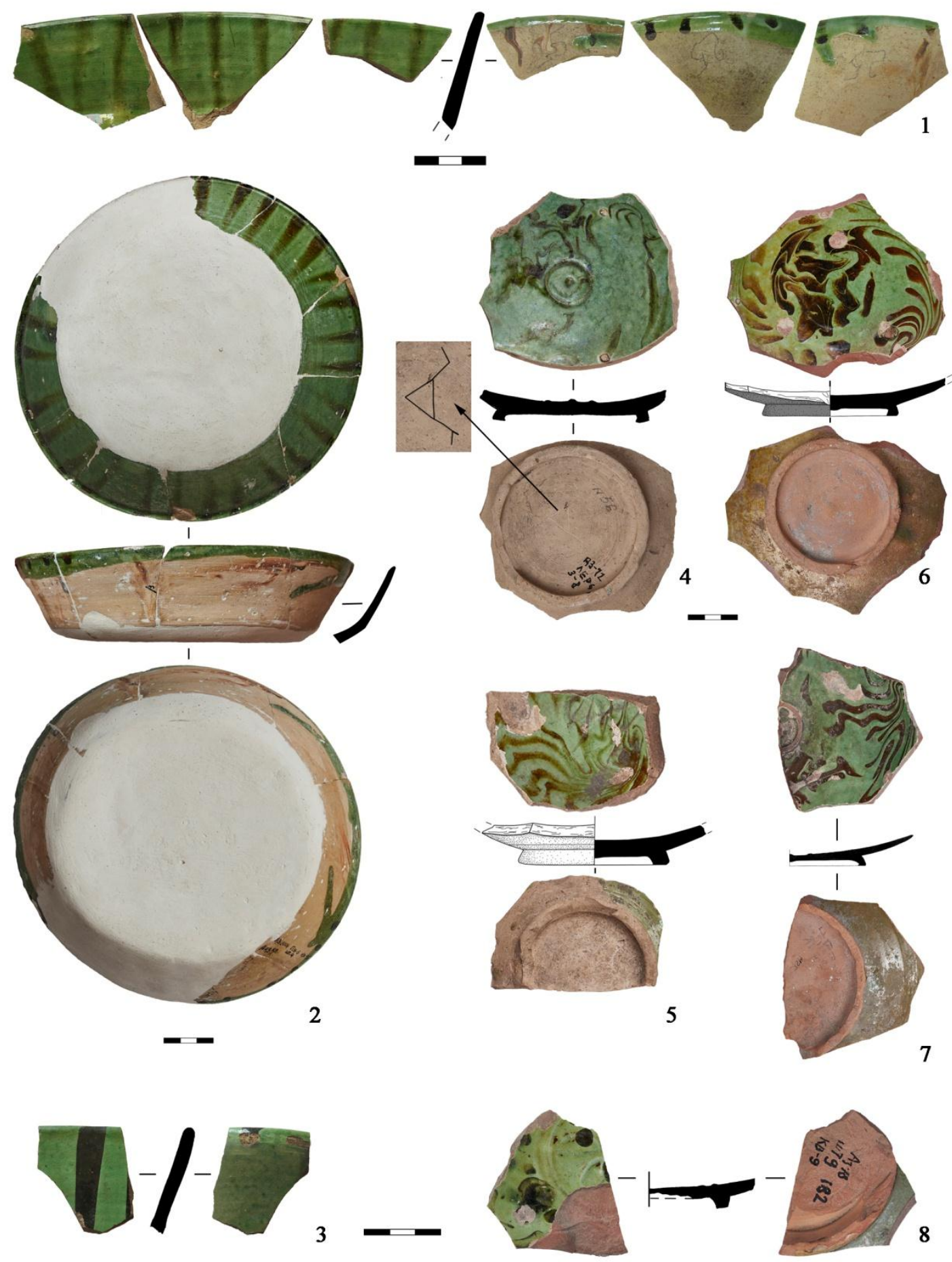

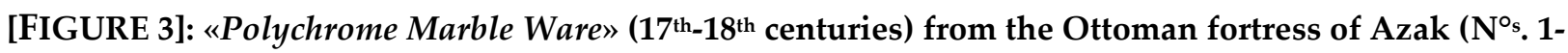
8). Open-shape vessels: Group 1. Pls: $\mathrm{N}^{\varsigma_{s}}$. 1-3 - subgroup 1.4; $\mathrm{N}^{\mathrm{s}_{s}}$. 4-8 - unidentified fragments. From the collection of the Azov Museum-Reserve (Azov, Russia).

Photos by IRINA GUSACH, 2020. 

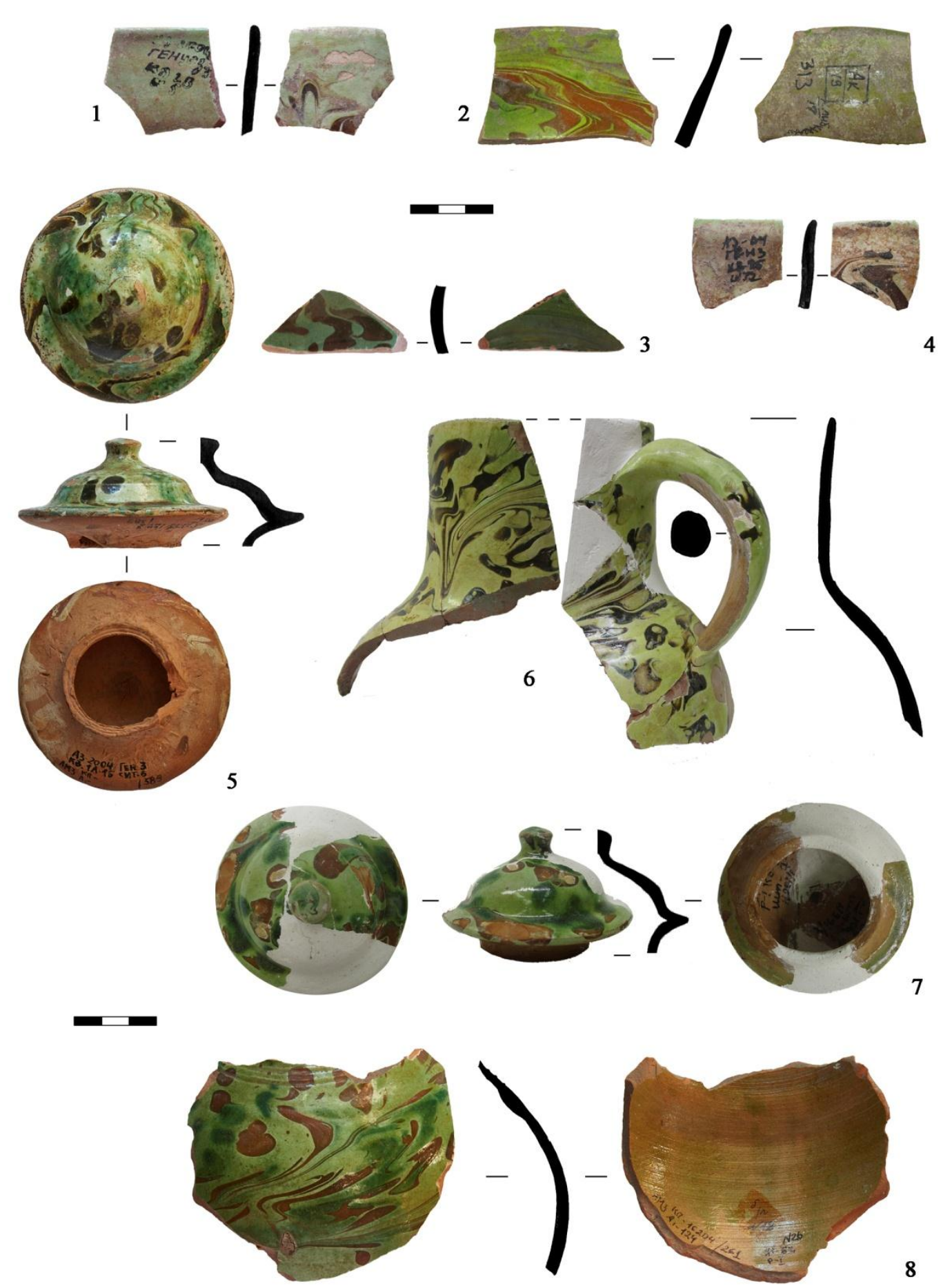

[FIGURE 4]: «Polychrome Marble Ware» $\left(1^{\text {th }}-18^{\text {th }}\right.$ centuries) from the Ottoman fortress of Azak $\left(\mathrm{N}^{\circ \mathrm{s}} .1-\right.$ 8). Open-shape vessels: Group 2. Bowls ( $\mathrm{N}^{\circ}$. 1-4). Close-shape vessels: Group 1. Jugs $\left(\mathrm{N}^{\circ} .6,6\right.$ ); Group 2. Jug lids $\left(\mathrm{N}^{\circ} .5,7\right)$. From the collection of the Azov Museum-Reserve (Azov).

Photos by IRINA GUSACH, 2020. 

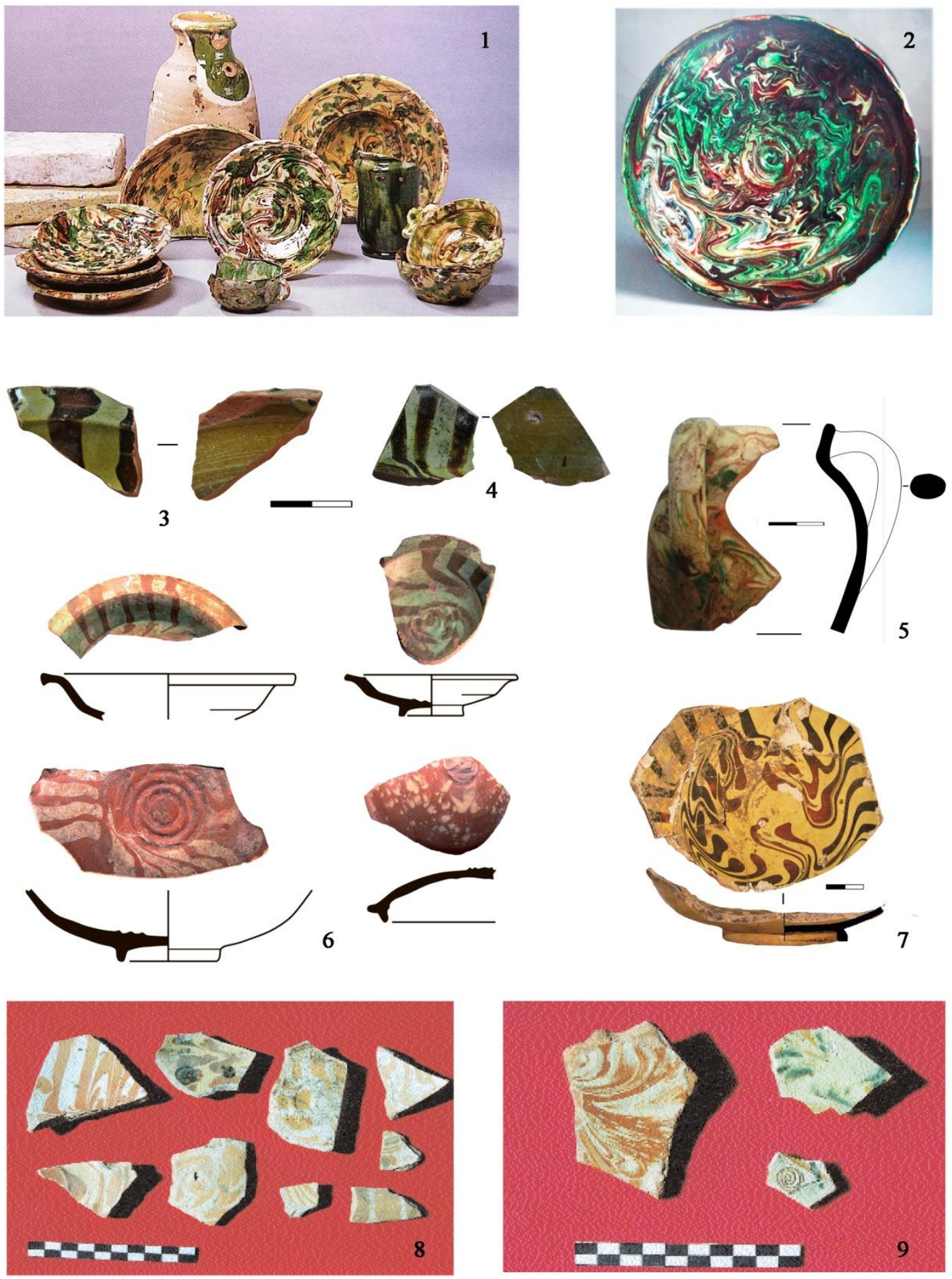

[FIGURE 5]: «Marmorizzata» ceramics. Northen Italy (16 ${ }^{\text {th }}-17^{\text {th }}$ centuries): 1 - Pisa (AMOURIC \& AL. 1999: FIG. 212); 2 - Tuscany. (MOORE VALERI 2012: FIG. 22); «Polychrome Marble Ware» $\left(1^{\text {th }}-18^{\text {th }}\right.$ centuries): 3, 4 - Gonio, Georgia (photos by IRINA GUSACH); 5 - Kamentz-Podolsk, Ukraine (photo by PAUL NECHITAYLO); 6 - Izmir, Turkey. (FRANÇOIS \& ERSOY 2011: FIG.9; 7 - Kholmsky-25,

Russia (photo by ALEX NECHIPORUK); 8, 9 - Istanbul (BARIŞTA 2002: fot.3, 10). 


\section{Walid cAli Khalil \& Irina Rudolfovna Gusach}

$$
\begin{aligned}
& \text { طرز وأنواع 》الفخار المطلى متعدد الألوان على شكل رخام" } \\
& \text { من قلعة آزاك العثمانية بجنوب روسيا (دراسة أثارية) } \\
& \text { وليد على محمد محمود خليل وايرينا رودالقوقنا جوساتش } \\
& \text { أستاذ الفنون والآثار الاسلامية المساعد- كلية الآثار / جامعة الفيوم }
\end{aligned}
$$

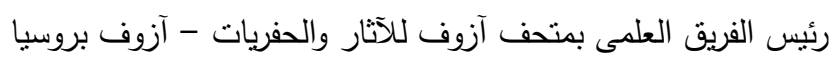

$$
\begin{aligned}
& \text { الملخص }
\end{aligned}
$$

«تهنم هذا البحث بدراسة نوع نادر جدًا من الفخار المطلى متعدد الألوان على شكل الرخام يPolychrome Marble Ware والذى تم اكتثافه خلال أعمال الحفر والتتقيب الأثرية فى جنوب روسيا بين عامى (197 و 10 ــrم فى قلعة آزالك العثمانية فى منطقة شمال شرق آزوف، وتعتبر هذه الدراسة من الدراسات النادرة فى روسيا النى تلقى الضوء على أهمية تلك الأوانى والثقافات الفخارية

$$
\text { الدحفوظة فى مجموعات بمخازن متحف آزوف للتاريخ والآثار وعلم الحفريات. }
$$

وقد اهتم الباحثين خلال الدراسة العلية الآتارية بتأريخ وتأصيل شقافات الفخار المطلى متعدد الألوان، وتحديد مراكز الإنتاج وتاريخ الصناعة، وكذللك تحديد وتصنيف أنواع وأثنكال هذه الأوانى الفخارية التى تم اكتثافها أثناء التتقيب فى قلعة آزالك التركية، ومحاولة خلق نوع من المقارنة مع مكتشفات مواقع أثرية أخرى من العصر العثمانى. تلك المحاولات التى ثم التوصل من خلالها إلى أن معظم الأوانى الفخارية متعددة الألوان على شكل الرخام مموضوع الدراسة- نم جلبها إلى قلعة آزاك التركية من الأناضول حيث نم إنتاجها خلال القرنين

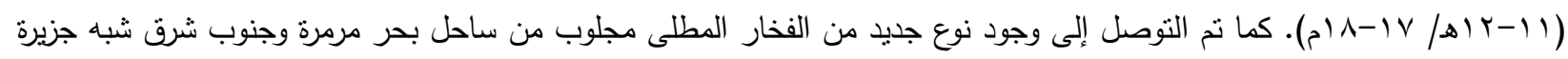
القرم، وعلى ماييدو أن خزافى القرم قاموا بتقليد الأوانى الفخارية الإيطالية والماليزية ذات الزخارف الرخامية والتى كانت منتشرة لديهم فى

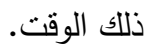
الكلمات الدالة: جنوب روسيا، قلعة آزالك العثمانية، الفخار المطلى متعدد الألوان، القرنين السابع عشر والثامن عشر. 